\title{
新刊書紹介
}

\section{近代日本の海洋調査のあゆみと水産振興 正しい観測結果はかけがいのない宝物}

中野 広著, 恒星社厚生閣 (2011 年)/B5 判, 323 頁, 8,400 円

海洋学の専門家でない著者が本書を著すきっかけは, 著者が東北水研在任中, 東北ブロック水産業関係試験研 究推進会議としてまとめた「海洋・資源のモニタリング 調査は未来への架け橋」（東北水研，2006 年）にあった と聞く。

本書の “はじめに”は「海洋調査をさらに発展させる には社会背景をふまえ, 過去から現在までの海洋調查に ついての取り組み，その考え方，それに関係した人々と 彼らの苦悩・苦労と成果を伝え, 社会の中での理解」 「地球温暖化なども含め海洋生態系が大きく変化してい る現在, 持続的に漁業を営み安定的に食料を供給する視 点から, 海洋調査, 特にモニタリング調査について新た な理論構築が重要」という背景と問題意識を掲げている。

各論では, 明治から戦前までの水産における海洋調査 を, 識者があまり触れていない漁業者や地方水試等の海 洋調査に関する意見や取り組み, 水産局の行政施策, 水 産講習所・農林省水産試験場の海洋調査についての具体 的な取り組み, 漁業・水産業の発展との関係などに焦点 をあてて体系化を論じている。巻末には原典・資料計 15 編を小フォントの字体で 70 頁にわたり収録。北原の 法則で知られる「海洋調查卜魚族ノ廻遊」(水産講習所 海洋調査部）などの公刊物が 13 編。他に，わが国の明 治期から戦前までの水産に抢ける海洋モニタリング調査 として各実施機関, 横断観測・定地・定点観測の地点, 実施期日の詳細な一覧に既往の文献を駆使, 照合した年 代記と, わが国漁業の発達と海洋調查関連事項について の 2 編。まさに水産・海洋調査のアーカイブス集大成 であり，次世代に伝える歴史の架け橋である。

また，本書は海洋モニタリングに焦点を当ててはいる が各章の末尾脚注には, 水産学関連のみならず時代を先 導した 120 名を超える人物の略歴・業績はもとより逸 話などが小フォントに詰めて詳細に記されている。多く は顔までが写真や素描で揭げられ, 活躍した先人達の実 像と時代背景に理解が深まる。

さらに, 最終章の “まとめ”では 28 頁にわたり冒頭 の問題意識を受けて,「生態系の管理, 健全な漁業生産 活動を維持するための土台」となる，モニタリング調査 の経済評価に関する論議を展開している。水産研究の発 展過程を通じて水産学の根幹に切り込む科学論としても 稀有の書であり，一読を抢勧めしたい。

（元水工研 鈴木秀爾）

\section{農・水産資源の有効利用と ゼロエミッション}

坂口守彦・高橋是太郎編 恒星社厚生閣（2011 年) /A5 判, 233 頁, 4,725 円

本書では, 農畜産業・水産業・食品産業の各分野にお ける未利用物の新たな利用法・利用技術, 廃棄物の再利 用技術などに関する最新の情報が紹介されており，この 分野に携わる方には必読の書であろう。

最初に本書が生まれた経過について若干説明しておく。 神日本水産学会の創立 70 周年記念事業の一環で, 「水 産物の有効利用法開発に関する国際シンポジウム」が企 画され, その後, プロシーディングをもとに, ELSEVIER から 2004 年に刊行されたのが, “MORE EFFICIENT UTILIZATION OF FISH AND FISHERIES PRODUCTS”である。また, 2005 年には, この書の 内容に新たな知見が加えられ本書の原型というべき “水 産資源の先進的有効利用法”が株式会社エヌ・ティー・ エスから刊行された。

一方, 平成 22 年には, 日本水産学会シンポジウム 「水産物の有効利用とゼロエミッション」が開催され, 本書はその記録をとりまとめたものとして刊行された。

内容を紹介すると, 第 I 部の「序論」では第 1 章 「現状と課題」; 第部の「農畜産・食品系産業の廃棄物 々有効利用」では第 2 章「農産系」。第 3 章「畜産系(1)」, 第 4 章「畜産系(2)」, 第 5 章「食品系」; 第部の「水 産廃棄物の有効利用」では第 6 章「雑魚・混獲魚」, 第 7 章「魚腸骨」, 第 8 章「藻類」, 第 9 章「貝殼」, 第 $\mathbb{N}$ 部の「厄介ものとその利用」では第 10 章「クラゲ類」, 第 11 章「ヒトデ」, 第 12 章「藻類」, 第 $\mathrm{V}$ 部の「ゼロ エミッションの実施例」では第 13 章「軟体動物の処 理」, 第 14 章「封蔵食品の製造と処理」, 第 15 章「排 水処理」と続き, 最後は「抢わりに」の V 部構成である。

ところで, ゼロエミッションの実現には, 技術論を超 えた包括的な思考が要求される。たとえば, 現在の資源 利用, 産業のあり方, 生産プロセスを含む産業全体のシ ステム, 消費者の消費パターン, ライフスタイルなどを 基本的に見直し，さらには経済システムを含んだ人間社 会全体の再設計が必要になる。

本書では, 有効利用とゼロエミッションの概念的な区 別に若干不明膫な点は見うけられるが，紹介されている 多くの実践事例や関連技術は, この分野の研究者・技術 者, 関連の行政機関, さらには市場関係者にとっても大 変, 有益なものとなるであろう。今後, 本書が多くの読 者の支持を得られることを期待したい。

（道工技セ 三浦汀介） 


\section{新刊書紹介}

\section{水圈環境教育の理論と実践一 水圏環境リテラシープログラム}

佐々木剛著, 成山堂書店 (2011)/A5 判, 224 頁, 2,520 円

魚介類や海藻, 漁具等ではなく,「人間」を主な研究 対象としている研究室が東京海洋大にある。

水圈環境教育学研究室。海洋や河川など水圈の環境を 観察し, 水圈をめぐる問題を深く考え, 確かな知識に基 づき責任ある行動をとれる人材育成を目指し, 新たな教 育の理念と方法に迫る研究室である。水圏環境に関する リテラシーを, 小学生から大人をで幅広く市民の間に普 及することができるエデュケーターの育成も手がける。

著者は, 水産高校教員を経て, 2006 年からこの研究 室で精力的に活動する 40 代の准教授である。現場体験 の重要さを説き, 学生とともに身軽に現場に出かけ, ア クションリサーチを実践しながら，独自に開発した環境 教育プログラムを展開する。幅広い人々を巻き込反, 彼 ら・彼女らの学びと変容をつぶさに見つめるのが, 著者 の研究スタイルである。

本書は, この分野の研究について, 学習理論の検討や 海外の動向を踏まえつつ, 著者自身が実施したフィール ドワークとその成果を紹介する形で構成されている。

たとえば，東京都大田区でのプログラム。参加した小 学生の過半数は, 事前アンケートに対して「人間と海の 生き物は, かかわりがないと思う」と答えていた。著者 らは, この小学生たちとともに東京湾のボラを解剖し, その胃の内容物と, 浜辺公園で採取した生物とを比べさ せる。この実体験を通じて, 小学生たちは自分の生活排 水が海の環境に与える影響に気づいていったという。

また, 岩手県の閉伊川流域では, 住民主体の水圈教育 を定着させるため, 地域住民を募り, 水圈環境エデュ ケーター養成講座「さんりく ESD 閉伊川大学校」(ESD は「持続可能な開発のための教育」の略）を開催した。

活動は海のない地域にも及ぶ。群馬県の利根沼田地域 では, 川と海とのつながりを学ぶ, 小学生対象のプログ ラムを実施した。スタッフを務めた地元高校生には、こ の経験が進路選択の参考になる効果もあったという。

水圈に関する近代的教育は, 日本では 19 世紀末の水 産伝習所（現東京海洋大海洋科学部）設立を瞢矢とし, 水産に携わる職業人の養成を中心に展開してきた。だが この先，持続可能な社会をつくっていくには，市民・消 費者に向けた水圏環境教育も欠か世ない。この著者の思 いが，本書の通奏低音をなしている。水圈・水産につい ての人材育成に，新たな百年の計を打ち立てようとする 一冊である。（北大高等教育推進機構 三上直之）

\section{日本の魚は大丈夫か}

勝川俊雄著, NHK出版 (2011 年)/新書判, 221 頁, 777 円

「漁業がヤバいって, 知ってた? ?」「漁業改革, 待っ たなし!」という帯封のキャッチコピーが示すと抢り， 日本漁業の「改革」を提言する書である。「日本漁業の 衰退は, 乱獲による資源枯渴の問題と根強く結びつい て」いるとの基本認識のもと,「(1)漁獲を一時的なもの でなく持続させるために『十分な親魚をとり残す』こと， (2)利益を上げるために『獲った魚をできるだけ高く売る』 こと」が重要であると説く。抢そらく，(1)，(2)の原則に は誰も異論はないだろうが，それを実現するための具体 策と経路については, 評者によってさまざまな意見があ ることだろう。私が本書を通読して印象的だったのは, 日本漁業の現状と改革提言を扱った第四章までと, 震災 復興の提言抢よび水産物の放射能污染を扱った第五, 六 章とでは, 文章のトーンがやや異なっている点である。

前者では,「日本の魚資源は乱獲により減少の一途」 「資源のほとんどが獲り尽くされ」「壊隇状態」「無規制」 「無管理」「補助金漬けで打先真っ暗」「公的資金で生活」 「もはや半失業者」などの言葉を並べて日本漁業の現状 を紏弾する。そこでは, 資源状態や経営状態, 漁協運営 実態等に関するモザイク性や, 関係者の努力は一切認め ず，シロかクロかの二值的な表現によって論を展開す る。一般読者を対象とする本書の性質上, 記述の正確性 はさておき，ストーリーのわかりやすさを優先した所以 であろうか。あとがきには「本書の内容だけをみて, 日 本の組合や漁業を全否定するのは間違いです」とある。

一方, 後者では,「経営統合による効率化」「養殖業の 協業化・集約化」「マーケティングの重要性」「生産者々 加工・流通業者の強力タッグ」「『人を呼べる』水産物づ くり」「水産業を核として, 地域が一体となる」「青年部 の地域プロジェクト」「人材育成」等の提言にもみられ るように, 漁業現場の比較的細部にまで目配りした論が 展開される。水産物の放射能污染の章では中立的・多角 的な視点から慎重な説明が心がけられている。

なお，本書とあわせて，小松正之著「海は誰のものか 一東日本大震災と水産業の新生プラン」マガジンランド (2011年 10 月) と, 全漁連「東北地方太平洋沖地震に よる被㷋漁業・漁村の復興再生に向けた有識者等検討委 員会『中間報告書』」（加瀬和俊委員長, 2011 年 7 月） (http: / / www.zengyoren.or.jp / oshirase / tyukan_houkoku.html）を読むと, それぞれの主張の共通点・相違 点が対比されて興味深い。（東大院農 山川 卓） 


\section{新刊書紹介}

\section{生鮮水産物の取引行動分析}

藤本宗一著, 成山堂書店 (2011年) / A5 判, 222 頁, 2,730 円

「日本に打ける水産物流通の特徵を簡単に述べてくだ さい」と質問されれば，筆者は「供給体制や流通経路は “複雑”ですが，消費地には安定して供給できる体制が 構築されています」と答えてしまう。流通に携わる方々 が, 豊富な種類, 供給先の違いや事情を理解し, 短い消 費期限の商品の安全を保っているからこそ，私たちは今 日も安心して水産物を口にできると考えているからであ る。本書は, いわばその “複雑さ”について, 永年魚市 場に勤務され，流通現場でのノウハウを熟知し，卸売市 場制度に関するエキスパートである著者が，水産物流通 に携わる関係者の行動について分析し, まとめた書籍で ある。

著者は,「都市生活者は大衆魚の生鮮消費を希望して いる」という前提と,「現在の卸売市場制度は生産者と 消費者に有効に機能しているのか」という問いを掲げ, 本書上梓の動機について「“量販店組織の効率市場販売 システムが, 生もの・生鮮での水産物消費を消去しよう としているのでは”という疑念からのもの」としている。 この観点から, 水産物流通史や卸売市場法の理念や時代 対応に触れながら, 昨今の水産物の供給状況, 漁業の生 産活動, 漁港・卸売市場の機能, 売買差益による市場関 係者の行動等について, 精繳な場合分けや分類がなさ れ，的確かつ丁寧に解説されている。

一般的に，産業活動に携わる人の行動についてまとめ られる書籍では, 聴き取り調査の結果や, 著者自身の体 験談を用いることによって, 臨場感のある論を進めるこ とが多い。しかしながら，本書ではこうした記載はほと んどなく, 統計データをもとに作成された視覚的に理解 しやすい種々のモデルを活用し，それでいて平易な説明 がなされている。著者は, あとがきにおいて, 流通理論 を用いて生鮮水産物取引行動の分析を試みるものではな く, 取引現場からの発信であり, そこでの体験につい て, 可能な限りの抽象化を試みようとした， と謙遜され ているが，流通の理論を把握したうえで，相当の現場経 験を積み重ねなければ, こうした書籍ををとめあげるこ とは不可能であろう。水産物流通に興味を示し, 学習し ようとする者は, 本書に出会うことによって, 取引行動 に関する理解がより深められ, 現場のニーズや研究の シーズを探求しようとする感性がより高をるに違いな い。

(農林水産政策研究所 高橋祐一郎)
水産学シリーズ 171

アンチェイジングをめざした水産物の利

用

平田 孝・菅原達也編, 恒星社厚生閣(2011 年)/A5 判, 128 頁, 3,780 円

近年，コラーゲンや $\mathrm{EPA}, \mathrm{DHA}$ ，アスタキサンチン など, 様々な水産物由来成分が機能性食品等へと応用さ れている。また，水産物成分を化粧品などに応用しよう という研究も多い。機能性食品と化粧品は, 素材や研究 手法に共通性があるものも多く, また, 対象とする研究 者層も重なる部分が多いと思われるが，これまでこれら を一括して扱う成書は少なかった。本書は,「アンチエ イジング」というキーワードで水産物由来成分の機能性 食品及び化粧品素材への利用に関する研究を同時に取り 上げることに成功している。慧眼であろう。

取り上げる範囲が広い分, 内容は, 機能性素材の調製 技術開発から臨床応用まで幅広く, 内容が散漫になりが ちな印象があるが，当該分野を広く概観したい向きには 好適であるといえる。

本書は大きく 3 編に分かれている。第一編は水産物 の多様な健康増進機能と題して, アンセリン, グルコサ ミン, カロテノイド, 魚油について, 素材開発から培養 細胞, 動物実験さらには臨床応用に至るまで様々な内容 が述べられている。第二編は近年もっとも注目を集めて いる, 脳機能に対する水産物によるアンチエイジング機 能とその評価手法について述べられている。この編で は, プラズマローゲンと DHA を取り上げて, 脳機能, 特にアルツハイマー病に対する予防・治療効果に関する 研究を取り上げている。また, 評価の難しい脳機能の最 新評価手法として，イメージングマススペクトロメト リーという手法を紹介し, 本手法によるマウス脳のリン 脂質の分析例などを示している。第 3 編は, 水産物由 来アンチエイジング素材として, ホタテガイ等軟体動物 のセラミド脂質抢よび，マリンコラーゲンの分布と抽出 技術について，また，マリンカロテノイドの分布と代謝 ・利用について述べられている。

このように, 水産物の機能性食品や化粧品への応用研 究をアンチエイジングというキーワードで切り取った本 書は, 当該分野の研究者のみならず, アンチエイジング 抢よびアンチエイジング素材に興味のある学生などにも 格好の参考書となりうるであろう。

（水研セ中央水研 石原賢司） 